\title{
Children and the Gods of War
}

\author{
David G. Smith
}

University of Lethbridge

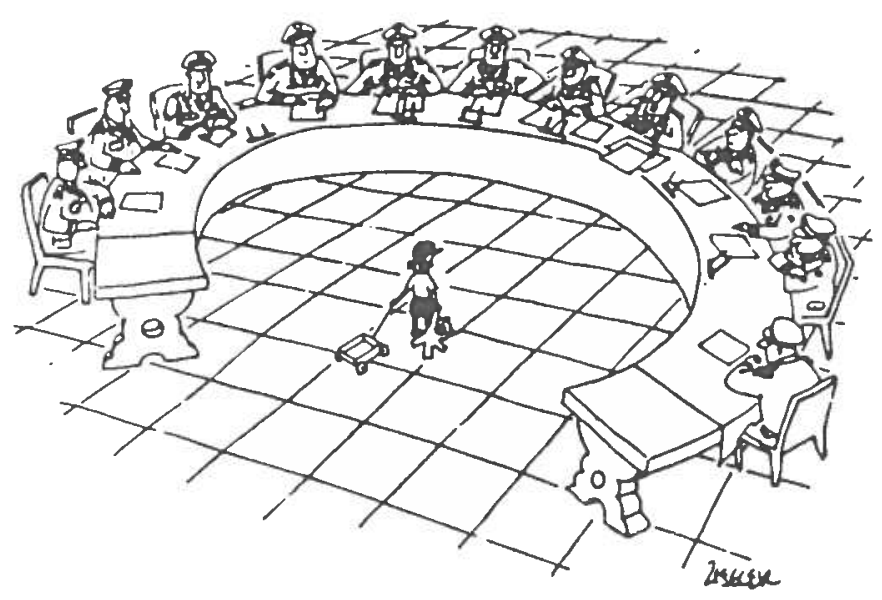

"And what can the Joint Chiefs of Staff do for you today, little girl?"

Drawing by Ziegler; (c) 1983

The New Yorker Magazine, Inc.

Reprinted with permission

A recent United Nations study on the effects of the arms race on daily life should invite us to think about the relationship between increasing global militarism and children. In 1981, $\$ 1$ million was spent on weapons every minute of every hour of every day (United Nations, 1983), and according to UNICEF director James Grant, every year 12 to 13 million children (the equivalent of 120 Hiroshimas) die from hunger and malnutrition largely because funds for social and economic development are everywhere being diverted to the stockpiling of arms and the development of standing armies (Toh, 1986).

So there is a certain irony in the New Yorker cartoon above, because what would the military mind accept as an answer to its own question about children? When the Joint Chiefs of Staff ask what they might do, today, for a child, as educators we should ask if this is a rhetorical question, a real question, or a nonquestion because there is much at stake in the answer. The irony may be that, faced with a child, the military mind is powerless. That is, the myths of "knowhow" and "can do" which underwrite all vulgar interpretations of 
what is required today, pedagogically speaking, may be incapable of understanding that what is needed in our relations with young people is of a different order.

Not long ago, in New York, there was a meeting of ambassadors from all the major world powers to discuss the question of nuclear disarmament. ${ }^{1}$ The meeting was both heated and fruitless as different parties argued fiercely for their own positions with no progress at all made in dismantling nuclear stockpiles. At a cocktail party afterward, however, a strange thing happened. One ambassador, who had just become a grandparent, enthusiastically pulled out a picture of his new grandchild to show the others. Before long all the members present were showing pictures of their children and grandchildren, nieces, nephews, and so forth; they were swapping stories, jokes, and comparing notes. Somehow the child had broken through the thick, dumb husks of adult politics, generations of hostility and antagonism, arrogance of opinion, and so forth, to bring people together at least for a moment.

Without being sentimental, what is at issue here for us as educators? I think it has something to do with the nature of power and the question of what it means to be adult in our relations with children. We might begin by interpreting the question of the Joint Chiefs, "What can we do for you today?" as a question of genuine bewilderment, a bewilderment coming from a world, a way of thinking, so far removed from the radical simplicity, the closeness to life which the child represents, that, in the presence of a child, the most sophisticated planners of strategy with all their information systems, and their short, medium, and long range geopolitical agendas, genuinely do not know what to do. But also, we hear in the Joint Chiefs' query all the false confidence and braggadocio that imbues the speech of those who feel themselves to be in ultimate charge of the essential categories of power, that is, in charge of the logics, rationales, conceptual schemes by which the world is to be understood. But it is precisely this confidence, this sure but foreclosed opinion, which produces the unproblematized, unreflective desire to "help" children. Education faculties are rife with this kind of powerful, confident assumption of knowing what to do with respect to children largely because they are foundationally deaf to the full question of what, in fact, children are for us.

Contemporary educational paradigms are implicitly and increasingly militaristic with respect to children (witness the plethora of books on discipline, control, management, and so forth) because they are based on the will-to-power and a form of thinking (Cartesian) which cannot tolerate difference, that is, which understands difference as a problem to be solved and subsumed under a condition of mastery and explanation. ${ }^{2}$ This way of thinking cannot articulate the way in which the full meaning of a child, for us, resides in the paradox of being part of us but also apart from us. So, as 
educators, we are in need of a new pedagogy which recognizes at its center the question of children as a question which calls for new selfreflection on our part. Hermeneutic studies of the meaning of children in the lives of adults (Smith, 1983) bring this theme home again, that living with children means living in the belly of a paradox wherein a genuine life together is made possible only in the context of an ongoing conversation which is never over, yet which also must be sustained for life together to go on at all. Homes, classrooms, schools, wherein the people in charge cannot lay themselves truly open to the new life in their midst, always exist in a state of war from which children are driven either inward or outward but never forward. The openness that is required is not a vacuous licentiousness but a risky, deliberate engagement full of the conflict and ambiguity by which new horizons of mutual understanding are achieved. This is the fundamental requisite for giving children a sense of membership in the human community, for one learns to find one's voice only in an environment where speech itself is well understood as having a listening aspect, and all that this entails phenomenologically.

John Martini's study (1987) of the "moments" of pedagogy involved interviewing teachers about those occasions when, as teachers, they felt something genuinely creative happened between themselves and their students. One common refrain spoke of a period of provocation or "calling" (Latin pro-vocare) from students followed by acts of anger, then conciliation on the part of the teacher. It is as if young people ask for, above all else, not only a genuine responsiveness from their elders but also a certain direct authenticity, that deep human resonance so easily suppressed under the smooth human-relations jargon teachers typically learn in college. Young people want to know if, under the cool and calm of efficient teaching and excellent time-on-task ratios, life itself has a chance, or whether the surface is all there is. And the best way to find out may be to provoke the teacher into showing himself or herself. How a teacher responds to that challenge determines whether a child will learn that growing up does not mean becoming forgetful about what it is like to grow, to be a child. For us as teachers, this means that we must become increasingly skilled in learning to read and understand our own childhoods, to understand our personal and collective pasts in a truly pedagogic way, that is, in a way that contributes positively and dialogically to a new understanding of and appreciation for the world. ${ }^{3}$

The most remarkable thing about contemporary North American teacher education may be that, in the name of inordinate concern for children, children themselves, as rightful persons in the total human drama, have been largely banished under a dense cover of rationalistic, abstract discourses about "cognition," "development," "achievement," and so forth. At a recent conference on gifted girls, one of the keynote speakers introduced her two-year-old daughter to me (first words) as being in the "96th percentile" on some 
important rating scale of ability. There is nothing wrong with this per se; we only want to ask if this is the most important, most valued, most attuned thing one would want to say about one's daughter, because it doesn't really help me to understand the daughter personally, uniquely, that is, in a way faithful to the daughter herself. Indeed, the most frightening thing about the new "science of teaching" studies geared to the "improvement of teaching" is that they are so rational, so clear, without doubt. But as such, they can tell us no more than a half-truth about the way life together is experienced at its fullest, most complex, and meaningful; in fact, in terms of teacher education, such proposals often cultivate the belief in student teachers that teaching is fundamentally an act of war. Many teachers have related to me that it took them several years of actual classroom practice to unlearn what they had learned in their teacher preparation programs.

The lack of credibility teacher education programs typically face in university and public domains may be due to the fact that we have yet to articulate the language for our special task-living and working with young people and all that this entails in our relations with the principalities and powers that be. Carrying on as a derivative discipline, particularly from psychology, has prevented us from facing the political and economic challenges that inevitably arise when one stands on the side of those whose future is still open. The old unilateral options of gericentrism (appealing to the authority of age, convention, tradition, nostalgia) and pedocentrism (child-centered pedagogy) only produce monstrous states of siege which are irresponsible to the matters at hand, that is, to the question of how life is mediated through relations between old and young. The recently reported "rising tide of youngsters in trouble" (Church, 1987) should be seen as a symptom of something horribly awry in the way we have thought about and organized our social, political, and economic lives because a child "in trouble" is a child without free, spontaneous, and friendly access to adult thought and action, a condition brought about when adults are too busy, too self-preoccupied, too enamored of their own projects to ask whether, in fact, their children have any clothes on. It takes a child to tell the truth on that score, and that is why to separate the voice of the young from the center of our planning about the future is singularly perilous. The Joint Chiefs' question of what to do must be understood as containing a genuine problematic, an invitation to those who consider themselves authorities on the subject of power to reconsider the nature of power in the light of what has just happened. Of course, in terms of the military, such questioning is unlikely to occur, but I hope for us as educators the lesson is not lost, not just because "children are our future" in some utopian, self-interested sense, but because our future is morally linked to the question of how we respond to new life in our midst here and now. We need to inquire critically and profoundly into all 
forms of thinking in our profession which take us away from our distinctly privileged mandate.

\section{Notes}

1. This story was related by Canadian Ambassador for Disarmament, Douglas Roche, at the International Institute for Peace Education, University of Alberta, Edmonton, Alberta, July 18, 1987.

2. I do not wish, here, to rehearse the history of the critique of Cartesian thinking. Interested readers should consult the works of J. Habermas, M. Heidegger, H.-G. Gadamer, and R. Rorty. A good exposition of these issues is contained in Barrett (1979). He describes the consequences of Cartesian epistemology this way: "Behind the faltering steps of the doubter marches the conquistador" (p. 126). Jacques Derrida is the writer most concerned with "difference."

3. See, for example, Britzman (1986). Also Butt \& Raymond (1987).

4. I am thinking here of the works of M. Hunter, J. Brophy, and B. Rosenshine.

5. This article has appeared in Elements, 19(1).

\section{References}

Barrett, W. (1979). The illusion of technique. New York: Anchor.

Britzman, D.P. (1986). Cultural myths in the making of a teacher: Biography and social structure in teacher education. Harvard Educational Review, 56(4).

Butî, R., \& Raymond, D. (1987). Arguments for using qualitative approaches in understanding teacher thinking: The case for biography. Journal of Curriculum Theorizing, 7(1).

Church, L. (1987, August 2). City's probation service stretched to crisis point. Calgary Herald, p. 1.

Martini, J. (1987). Teaching moments. Unpublished manuscript, University of Lethbridge, Alberta.

Smith, D.G. (1983). The meaning of children in the lives of adults: A hermeneutic study. Unpublished doctoral dissertation, University of Alberta.

Toh, S. (1986). Survival and solidarity: Australia and third world (south) peace. Social Alternatives, 6(2), 59.

United Nations. (1983). Economic and social consequences of the arms race and of military expenditures. New York: Author. 